\title{
FAKTOR INTERNAL MOTIVASI, COPING, MOOD DAN RELAPS PADA KASUS PECANDU NARKOBA
}

\author{
Irwan Syuhada \\ Fakultas Kedokteran Universitas Islam Al-Azhar \\ J1. Unizar No.20 Turida Mataram
}

\begin{abstract}
ABSTRAK
Relaps merupakan perilaku penggunaan kembali narkoba setelah menjalani penanganan secara rehabilitasi yang ditandai dengan adanya pemikiran, perilaku dan perasaan adiktif setelah periode putus zat. Secara garis besar ada dua faktor yang mempengaruhi terbentuknya relaps yaitu faktor internal dan faktor eksternal dari individu. Skala yang digunakan untuk mengukur faktor internal motivasi, mood, dan coping adalah skala SCL 90 (skala klinis 90). Skala SCL ini bisa digunakan untuk mengungkap aspek motivasi, mood, dan coping.
\end{abstract}

Kata Kunci: Relaps, Motivasi, Mood, Coping, SCL 90.

\section{PENDAHULUAN}

Saat ini banyak sekali kasus pengguna narkoba yang bisa dikatakan jatuh bangun dalam usahanya untuk berhenti mengkonsumsi narkoba. Setelah mencandu narkoba, individu biasanya berhenti untuk beberapa waktu setelah melewati masa putus zat yang menyakitkan dan masa rehabilitasi. Namun demikian, seperti tidak ada efek jera, individu kembali mengkonsumsi narkoba (Kamus Narkoba, 2006).

Data dari Badan Narkotika Nasional (BNN) menunjukkan pada tahun 2006 di lembaga Balai Kasih Sayang Pamardi Siwi BNN menunjukkan bahwa terdapat 38 kasus relaps berkali-kali dan masuk kembali ke lembaga rehabilitasi yang sama. Tahun 2007 tingkat relaps sebesar 95\% bahkan ada residen yang masuk untuk ke empat kalinya ke lembaga rehabilitasi tersebut. Tahun 2008 menunjukkan data relaps di indonesia mencapai 90\% (www.bnn.go.id).
Berdasarkan hasil perhitungan estimasi yang dilakukan oleh Badan Narkotika Nasional (BNN) diperkirakan ada 3,2 juta orang $(1,5 \%$ populasi $)$ di indonesia mempunyai riwayat menggunakan Napza dan dari jumlah tersebut diperkirakan hanya $10 \%$ yang mendapatkan layanan dari tenaga kesehatan.Selama ini hanya beberapa sarana pelayanan kesehatan termasuk rumah sakit umum dan rumah sakit jiwa daerah yang memberikan pelayanan pengobatan terhadap gangguan penggunaan napza, padahal diharapkan semua rumah sakit umum dan rumah sakit jiwa mampu memberikan pelayanan untuk kasus -kasus gangguan penggunaan napza (Kemenkes, 2012).

\section{Relaps \\ Relaps merupakan perilaku penggunaan kembali narkoba setelah menjalani penanganan secara rehabilitasi yang ditandai dengan adanya pemikiran, perilaku, dan perasaan adiktif setelah}


periode putus zat (e.g. Hubbard et. al, 2001).

Dalam bentuk yang paling dasar relaps merupakan kelanjutan dari perilaku yang bermasalah, klien yang mengalami perilaku adiktif dengan mudah mengakui bahwa akan berhenti sementara untuk mengkonsumsi zat adiktif, relaps ini merupakan masalah yang paling menantang yang dihadapi oleh mereka yang bekerja dibidang peilaku adiktif (Connors \& Maisto, 2006).

Proses relaps bervariasi pada setiap individu tergantung kontekstual individu dan faktor pemicu, secara garis besar ada dua pola dasar relaps yaitu overall metapattern of relaps dan more individual pattern that occur in general stages. Pola yang pertama terdiri dari peristiwa tertentu atau langkah-langkah yang mengarah ke relaps seperti mantan pemakai narkoba yang mengalami stres sehingga individu menjadi lebih mudah marah dan gelisah karena stres yang terus menerus dan hal inilah yang menyebabkan pandangan bahwa yang individu butuhkan adalah nrkoba (Marlatt \& Gordon, 1985). Sedangkan untuk pola kedua lebih lebih mengarah ke masalah keluarga yang dapat menimbulkan muculnya kembali perilaku relaps, Carich dan Stone $(1993,1994)$.

Relaps dapat terjadi apabila individu bergaul kembali dengan teman-teman pemakai narkoba atau bandarnya,
Individu tidak mampu menahan keinginan atau sugesti untuk memakai kembali narkoba dan individu mengalami stres atau frustasi (Goeders, 2004).

Ada beberapa pendapat mengatakan bahwa darah dalam tubuh seseorang pecandu narkoba sudah terkontaminasi zat-zat yang terkandung dalam obat terlarang sehingga individu yang sudah berhenti, kembali mengkonsumsi (Kamus Narkoba 2006).

Oleh karena itu terapi detoksifikasi seringkali dilakukan dengan tujuan untuk dapat menghentikan kecanduan. Namun demikian pada intinya, kesadaran dan niat penuh dari dalam hati merupakan senjata yang paling ampuh untuk memerangi keinginan. Penyembuhan secara fisik saja tidak cukup, karena penyembuhan mental sangat di perlukan (Kamus Narkoba, 2006). Relaps biasanya dipandang sebagai indikasi gagalnya suatu program penanganan atau individunya atau keduanya (Yuet Wah, 2005).

$$
\text { Barlow dan Durand }
$$
menggolongkan berbagai macam zat ke dalam empat bagian besar, pertama depresan merupakan zat-zat yang menyebabkan timbulnya efek perilaku tenang (sedatif) termasuk didalamnya antara lain alkohol, obat-obatan sedatif, hipnotik dan anxiolyctic dari kelompok barbiturates dan brenzodiazepines. Kedua stimulan adalah zat-zat yang membuat orang menjadi lebih aktif dan waspada, 
dan juga dapat meningkatkan mood. Termasuk jenis ini antara lain amphetamin, kokain, nikotin, dan kafein. Ketiga opiat yang merupakan zat yang memiliki efek utama menimbulkan analgesia (mengurangi rasa sakit) temporer dan euforia, dalam hal ini contohnya heroin, opium, kodein, dan morfin. Keempat halusinogen adalah zatzat yang menghasilkan delusi, paranoid, halusinasi, dan memicu persepsi sensoris. Termasuk dalam kelompok ini antara lain mariyuana dan LSD.

Dampak dari akibat penggunaan narkoba sebenarnya banyak macamnya. Namun secara umum dampak tersebut dibagi menjadi dua yaitu dampak secara psikis dan dampak secara sosial, diluar jenis tersebut masih ada efek merugikan lain yang jumlahnya tidak kalah banyak seperti efek terhadap kesehatan tubuh (Fausiah \&Widury, 2007).

Untuk dampak psikis akibat yang sering muncul adalah pengguna menjadi sangat menurun produktivitasnya, kehilangan rasa percaya diri, memiliki sifat apatis serta mudah curiga kepada orang lain bahkan kepada orang terdekatnya seperti orang tuan atau saudara kandungnya sendiri. Sedangkan untuk dampak sosial akibat yang sering muncul adalah pengguna dikucilkan oleh masyarakat karena dianggap merupakan orang yang berperilaku kurang baik dan merugikan. Dan untuk para pengguna yang relaps efek yang ditimbulkan adalah dosis pemakaian yang semakin meningkat dari sebelumnya (Fausiah \& Widury, 2007).

Hasil penelitian yang berupaya mengungkapkan faktor-faktor penyebab terjadinya relaps. Secara garis besar, penyebab terjadinya relaps yang disebutkan oleh studi-studi sebelumnya dapat digolongkan menjadi faktor internal dan faktor eksternal. Berbagai macam faktor penyebab relaps ini menjadi masalah dan tantangan utama bagi para mantan pengguna untuk tidak kembali mengkonsumsi narkoba (relaps).

Faktor internal yang diketahui memiliki pengaruh terhadap terjadinya relaps yakni efikasi diri, motivasi, craving, coping, emotional states, dan outcome expetancies (Witkiewitz \& Marlatt, 2004); stres (Sinha, 2001); conduct problem (Brown et al, 1996); depresi dan gangguan kecemasan (Cornelius et al; Bradizza, Stasiewics, Pass, 2006); serta Mood (Imani et. al, 2012).

Faktor eksternal yang memiliki pengaruh terhadap relaps yaitu konflik interpersonal dan tekanan sosial (Imani, Sebetimani, Ghojur, 2012); dukungan sosial dan sejarah keluarga (Witkiewitz \& Marlatt, 2004); serta sosial keluarga, lingkungan, dan economic employment environment (Sanchez Hervas, et al, 2012). 


\section{Motivasi, Mood, dan Coping}

Motivasi dalam faktor internal memainkan peranan penting dalam pembentukan perilaku relaps, dimana motivasi membantu individu untuk keluar dari kondisi stres yang akut sehingga individu bisa menahan dan mengendalikan diri untuk tidak relaps dalam penyalahgunaan zat adiktif (Sinha, 2001).

Motivasi berhubungan dengan proses terbentuknya relaps dalam dua cara yaitu motivasi perubahan perilaku positif dan motivasi untuk keluar dari perilaku yang bermasalah, perbedaan motivasi ini menggambarkan keinginan dan usaha individu untuk mengubah perilaku adiktif (Miller \& Rollnick, 2002).

Coping yang positif diperlukan oleh individu untuk tidak kembali relaps mengkonsumsi zat adiktif, coping sangat dibutuhkan sebagai pendekatan dan penghindaran untuk mengatasi stress dan godaan yang memicu individu kembali untuk relaps (Shiffman, 1984).

Kondisi yang memiliki resiko tinggi bagi para pemakai narkoba untuk relaps mencakup suasana mood yang positif atau negatif, individu yang memiliki penyesuaian negatif akan menunjukkan self efficacy diri yang tidak efektif sehingga kondisi ini dapat membentuk suasana mood yang tidak baik dan hal ini dapat memicu faktor untuk relaps (Imani, et. al, 2012).

Dalam sudut pandang psikologis salah satu motif utama penggunaan zat adiktif adalah untuk meningkatkan mood, sehingga zat bernilai positif karena meningkatkan mood positif dan mengurangi mood negatif serta dapat mengurangi stres an ketegangan (Imani, et. al, 2012).

Sosiokultural menekankan pentingnya peran kelompok, orang tua, serta media dalam menentukan perilaku yang dapat diterima dan yang tidak, antara lain bagaimana contoh yang diberikan keluarga berperan dalam pembentukan penyalahgunaan zat dan penting juga untuk diperhatikan adalah ketersediaan zat di lingkungan jika banyak zat diperjualbelikan akan menimbulkan kecendrungan ke arah penyalahgunaan zat (Fausiah \& Widury, 2007).

Dalam persepektif biologis kebanyakan riset faktor biologis adalah dalam rangka menemukan kemungkinan diturunkannya secara genetis predosposisi untuk mengalami masalah yang berhubungan dengan zat (Fausiah \& Widury, 2007).

\section{Definisi Operasional}

Faktor internal merupakan kondisi dari individu yang diketahui memiliki pengaruh terhadap terbentuknya perilaku 
relaps pada pemakai narkoba. Dalam penelitian ini, peneliti akan mengungkap dominasi faktor internal motivasi, mood dan coping dalam membentuk perilaku relaps pada pemakai narkoba.

Motivasi dalam faktor internal memainkan peranan penting dalam pembentukan perilaku relaps, dimana motivasi membantu individu untuk keluar dari kondisi stress yang akut sehingga individu bisa menahan dan mengendalikan diri untuk tidak relaps kembali.

Coping yang positif diperlukan oleh individu untuk tidak kembali relaps, coping sangat dibutuhkan sebagai pendekatan dan penghindaran untuk mengatasi stress dan godaan yang memicu individu untuk kembali relaps.

Kondisi mood yang positif atau negatif, Individu dengan coping yang negatif memiliki kemungkinan untuk relaps kembali sangat besar.

\section{Skala Ukur}

Skala yang digunakan untuk mengukur motivasi, mood,dan coping adalah skala SCL 90 (skala klinis 90), SCL 90 ini bisa digunakan untuk mengungkap aspek motivasi, mood, dan coping.

\section{KESIMPULAN}

Berdasarkan penjelasan berbagai macam faktor -faktor penyebab relaps diatas, penulis lebih mengkhususkan diri pada pembahasan faktor internal penyebab relaps. Pada penelitian ini, penulis memusatkan perhatian pada faktor-faktor internal yang dapat dikontrol. Faktor internal yang dapat di kontrol adalah motivasi (Witkiewitz \& Marlatt, 2004, coping (Witkiewitz \& Marlatt, 2004), dan mood (Imani, et. al, 2012).

\section{DAFTAR PUSTAKA}

Ametembun, M. T., (2003). Drug prevention and treatment program. Dept. Mental health John Hopkin Unniversity Maryland ( Humprey Fellow).

Barlow, David H., Durand, V. Mark. (1995). Abnormal Psychology: an Integrative Approach. Pacivic Groove: Brooks/Cole Publishing Company.

BNN. Kamus Narkoba. (2006).

Bradizza, C. M., Stasiewicz, P. R., \& Paas, N. D. (2006). Relapse to alcohol and drug use among individuals diagnosed with cooccurring mental health and substance use disorders. Clinical Psychology Review, 26, 162- 178.

Carich, M. S., \& Stone, M. (Eds.). (1993). Offender Relapse Prevention. Chicago:Adler School of Professional Psychology.

Carich, M. S., \& Stone, M. H. (1994). The targeted dysfunctional behavior cycle. Interventions, 1(1), 4-11

Chung, T., \& Maisto, S. A. (2006). Relapse to alcohol and other drug use in treated adolescents and reconsideration of relapse as a change point in clinical course. Clinical Psychology Review, 26, 149- 161 . 
Connors, G. J., \& Maisto, S. A. (2006). Relapse in the addictive behaviors. Clinical Psychology Review, 26, 107- 108 .

Fausiah, Fitri \& Widury, Julianti. (2007). Psikologi Abnormal Klinis Dewasa. Universitas Indonesia Press, Jakarta.

Geoders, N. E. (2004). Stress, motivation, and drug addiction. Current Directions in Psychological Science, 13(33).

Imani, Z., Sabetimani, M., \& Ghojur, K. A. (2011). Study of the effectiveness of cognitive group therapy in relapse prevention among substance abusers. Asian Journal of Medical and Pharmaceutical, 2(3), 47-52.

Keputusan Menteri Kesehatan Republik Indonesia. (2012). Pedoman Penatalaksanaan Medik Gangguan Penggunaan Napza, Direktorat Bina Kesehatan Jiwa Republik Indonesia.

Larimer,M. E., Palmer, R. S., \& Marlatt, G. A. (1999). Relapse prevention: An overview of Marlatt's cognitivebehavioral model, 23(2).

Miller, W. R., \& Rollnick, S. (2002). Motivational interviewing: Preparing in people for change (2nd ed). New York: Guilford press.

Marlatt, A., \& Gordon, J. R. (Eds.). (1985). Relapse prevention: Maintenance strategies in the treatment of addictive behavior. New York:Guilford.

Sinha, R. (2001). How does stress increase risk of drug abuse and relapse? Psychopharmacology, 158, 343-359.

Shiffman, S. (1984). Coping with to smoke. Journal of Consulting and Clinical Psychology, 52, 261-267.

Sánchez-Hervás, E., et al. , (2011).Psychosocial predictors of relapse in cocaine-dependent patients in treatment. The Spanish Journal of Psychology, 15 (2), 748755 .

Witkiewitz, K., \& Marlatt, G.A. (2004). Relapse prevention for alcohol and drugs problems. American Psychologist, 59(4), 224-235.

Yuet-wah, C., et al. Between abstinence and relapse: The role of "prerelapse abstinence" in drug rehabilitation in Hong Kong.

www.bnn.go.id, Data Kasus Narkoba, (akses 23 mei 2013). 